\title{
Efficient method for Agrobacterium-mediated genetic transformation of tobacco nodal segments
}

\author{
R.G. da Silva ${ }^{1}$, J.S. Coppede ${ }^{2}$, J.O.L. Silva ${ }^{2}$ and S.M. Zingaretti ${ }^{12}$ \\ 1 Universidade Estadual Paulista, Faculdade de Ciências Agrárias e \\ Veterinárias, São Paulo, Brasil, \\ 2 Departamento de Biotecnologia, Universidade de Ribeirão Preto, São \\ Paulo, Brasil.
}

Corresponding author: S. M. Zingaretti

E-mail: szingaretti@unaerp.br

Genet. Mol. Res. 17 (4): gmr18072

Received July 03, 2018

Accepted October 26, 2018

Published November 13, 2018

DOI http://dx.doi.org/10.4238/gmr18072

\begin{abstract}
Plant transformation is a widely used procedure for obtaining transgenic plants and to develop plant models to understand gene function. Plant models such as Nicotiana tabacum are widely used for understanding gene responses to external influences. An important tool in such studies is genetic transformation through infection with Agrobacterium tumefaciens. However, this transformation is often inefficient. Consequently, development and optimization of techniques to promote high rates of seedling regeneration of transgenic tobacco is imperative. The methods tested for infection of tobacco explants consisted of injecting $10 \mu \mathrm{l}$ of the bacterial culture directly into anodal segment using an insulin syringe (1 $\mathrm{mL}$ ); bacterial co-cultivation with nodal segments and micro-sectioned leaf disks. Infection through punctures made with a syringe in nodal segments of tobacco and no co-cultivation period was the most efficient in the regeneration process and in obtaining genetically transformed plants, with 88 and $75 \%$ success rates, respectively. We obtained an increase of $50 \%$ in the transformation rates when compared to previous studies using $N$. tabacum.
\end{abstract}

Key words: Explant; Method; Regeneration; Transgenic 


\section{INTRODUCTION}

Since the 1980s, Agrobacterium tumefaciens, a soil bacterium and the causative agent of crown gall disease (Horsch et al. 1984) has been of interest to plant scientists (Bottino et al. 1989). Agrobacterium is able to transfer and integrate a region containing the sequence of a tumor inducing plasmid (Ti-plasmid) into a plant nuclear genome (Gelvin 2003; Brasileiro and Aragão 2010). Several methods for plant transformation have been developed, including electroporation, protoplast culture, biolistic transformation (Nester et al. 1984; Brasileiro and Aragão 2010).

The agrobacterium transformation method is the most widely used method of gene transfer available for higher plants (Bottino et al. 1989), because it involves simple execution protocols and gives satisfactory transformation efficiency (Ribeiro et al. 2010). Several tissues and organs can be used as explants in plant transformation, including leaves, callus, roots, cotyledons, and shoots (Bottino et al. 1989). The efficiency of plant transformation is a result of the combination of various factors, including the method used, the species and also Agrobacterium strain specificity. It is known that the Ti-plasmid is most frequently responsible for determining the host range of natural isolates of Agrobacterium (Nester et al. 1984). An efficiency of $37 \%$ using a cotyledonary node in Glycine max (Olhoft et al. 2004), from 30 to $48 \%$ using a Oriza sativa embryo callus (Sallaud et al. 2003; Kim et al. 2003), and 62\% in Triticum aestivum immature embryos (Wu et al. 2003, 2006) had been reported.

In the last decades, several methods have been developed and changes incorporated in the transformation process via A. tumefaciens, such as the addition of acetosyringone and changes in the periods of co-cultivation for increased efficiency (Mayo et al. 2006; RibeiroNeto et al. 2015). Studies on plant models such as Arabidopsis thaliana and Nicotiana tabacum, which have useful characteristics, such as short generation time and large numbers of progeny (Sparkes et al. 2006; Xiao et al. 2015), help in the development of improved plant transformation methods for studying genes of interest (Begcy et al. 2012).

Efficient methods for introducing cloned genes into plants are important for understanding plant gene expression (Horsch et al. 1985). Agrobacterium is a tool that can help us to understand some of the most fundamental plant processes (Klee et al. 1987). We developed a new, robust and efficient method for infection, regeneration and genetic transformation of nodal segments of $N$. tabacum via A. tumefaciens.

\section{MATERIAL AND METHODS}

\section{Biological Material}

We used nodal segments $(3 \mathrm{~cm})$ and foliar disks $(1 \mathrm{~cm}$ diameter $)$ of wild-type (Xanthi) tobacco (N. tabacum) seedlings, pre-germinated in vitro, in a growth room under controlled conditions from plants 25 days of age. In the transformation process, we used competent cells from two bacterial strains; Escherichia coli DH10B for the assembly of the expression vector and A. tumefaciens strain EHA105 for the indirect transformation of the plant. For $E$. coli culture, 2xTY medium plus streptomycin $(30 \mu \mathrm{g} / \mathrm{mL})$ was used, while $A$. tumefaciens was grown in LB medium containing rifampicin $\left(75 \mathrm{mg} \mathrm{L}^{-1}\right)$ (Sambrook and 
Russell 2001). Before transformation, optical density values for the cultures of the two strains were 0.6 and $0.52 \mathrm{~nm}$ for DH10B and EHA105, respectively.

\section{Infection Methods}

All explants (32 nodal segments and 16 leaf disks) used in the process were initially disinfected in a laminar flow chamber by immersion in $70 \%$ ethanol and sterile water. The methods used in the infection of the tobacco explants with A. tumefaciens carrying the recombinant plasmid were:

i. Infection of nodal segments using a $26 \mathrm{Gx} 1 / 2$ " needle (SY). Small punctures in the meristematic area of the segments were made using the needle and $10 \mu \mathrm{L}$ of $A$. tumefaciens solution $(100 \mathrm{mg} / \mathrm{mL})$ with plasmid was injected in the perforation with a syringe., The explants were immediately transferred to flasks with solid MS medium (Murashige and Skoog 1962) containing $30 \mathrm{~g} \mathrm{~L}^{-1}$ sucrose $\left(\mathrm{C}_{12} \mathrm{H}_{22} \mathrm{O}_{11}\right)$ and $2.5 \mathrm{~g} \mathrm{~L}^{-1}$ phytagel (Sigma, USA), pH 5.8. Over the puncture region, $250 \mu \mathrm{L}$ of acetosyringone $\left(0.02 \mathrm{~g} \mathrm{~L}^{-1}\right)$ was applied; a co-cultivation period was not included.

ii. Nodal segments were maintained in static co-cultivation with $A$. tumefaciens (NS) culture. Nodal segments with small wounds, caused by a sterilized scalpel, were kept in a sterile polypropylene tube $(15 \mathrm{~mL})$ containing $3 \mathrm{~mL}$ of a solution of A. tumefaciens $(100 \mathrm{mg} / \mathrm{mL})$ plus $250 \mu \mathrm{L}$ of acetosyringone $\left(0.02 \mathrm{~g} \mathrm{~L}^{-1}\right)$, for a 30 minute co-cultivation period, and then transferred to flasks containing solid MS medium.

iii. Tobacco leaf disks co-cultivated with A. tumefaciens (FD). Leaves disks 1 $\mathrm{cm}$ in diameter were maintained for 30 minutes in a sterile polypropylene tube $(15 \mathrm{~mL})$ with $3 \mathrm{~mL}$ of A. tumefaciens cell suspension $(100 \mathrm{mg} / \mathrm{mL})$ plus $250 \mu \mathrm{L}$ of acetosyringone $\left(0.02 \mathrm{~g} \mathrm{~L}^{-1}\right)$ for co-cultivation, and then transferred to flasks with solid MS medium.

Control treatments (syringe method, leaf disks and nodal segments), without the use of A. tumefaciens, were performed simultaneously with the Agrobacterium-mediated infection methods.

Figure 1 illustrates the syringe method; it consisted of needle contact with the circular portions of the yolk segment, different from the procedures adopted in leaf disks and nodal segments, where the explants were immersed in a solution containing $A$. tumefaciens in suspension and acetosyringone.

Flasks with infected and control explants were kept in a growth chamber with a light-dark photoperiod of $16 / 8 \mathrm{~h}$, relative humidity of $70-80 \%$ and temperature of $22 \pm 2^{\circ} \mathrm{C}$. After 72 hours, the infected explants were transferred to new flasks containing solid MS medium with cefotaxime antibiotic $\left(500 \mathrm{mg} \mathrm{L}^{-1}\right)$ for elimination of bacteria and kanamycin $\left(50 \mathrm{mg} \mathrm{L}^{-1}\right.$ ) for transformant selection. Explants were transferred, every 20 days, to new flasks with MS medium containing cefotaxime at decreasing concentrations of $250 \mathrm{mg} \mathrm{L}^{-1}$, $125 \mathrm{mg} \mathrm{L}^{-1}, 62.5 \mathrm{mg} \mathrm{L}^{-1}, 31.25 \mathrm{mg} \mathrm{L}^{-1}$ and $0 \mathrm{mg} \mathrm{L}^{-1}$ for complete elimination of $A$. tumefaciens. 


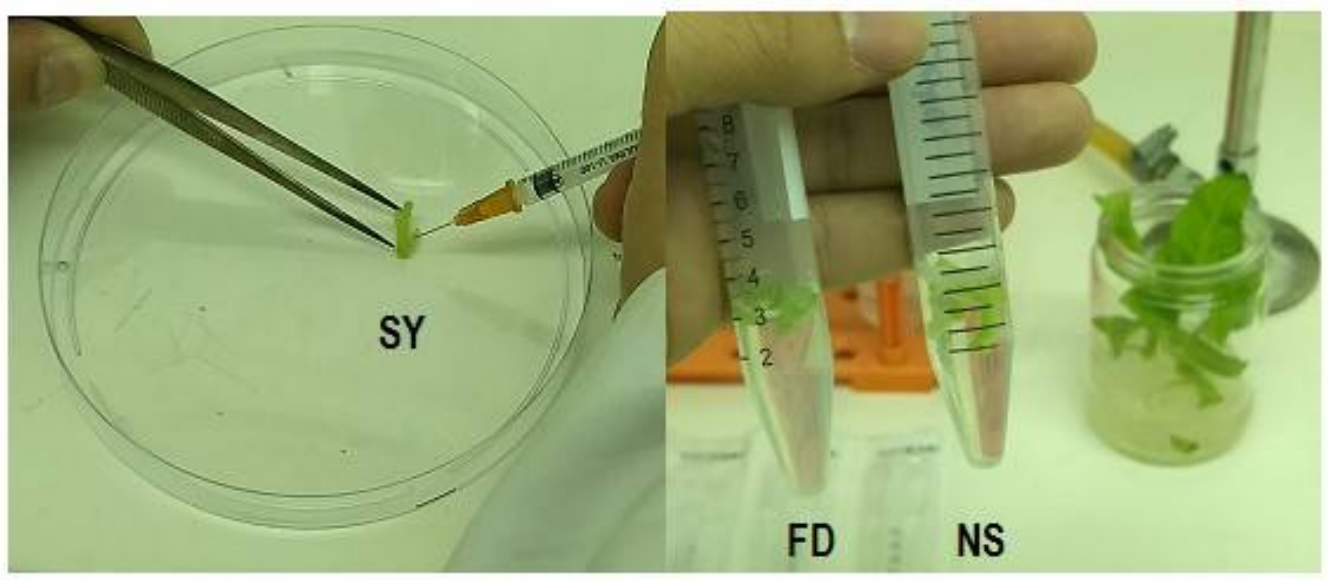

Figure 1. Infection methods for tobacco explants. (SY): infection of nodal segments with a syringe; (FD): tobacco leaf disks in contact with Agrobacterium tumefaciens; (NS): nodal segments maintained at rest with A. tumefaciens.

After plant regeneration, DNA was extracted from leaves (Doyle and Doyle 1987) and confirmation of the transformants made by PCR. The number of positive events for each method tested was used for regeneration and transformants percentage calculation.

\section{RESULTS AND DISCUSSION}

After the plant regeneration period, complete emergence of the first leaves and roots at 20 days growing in $0 \mathrm{mg} \mathrm{L}^{-1}$ cefotaxime, differences in regenerated and transformed plants percentages were observed for the Agrobacterium-mediated infection methods (Table $1)$.

Table 1. Preparation time, regeneration and transformed plant rates by the different methods.

\begin{tabular}{ccccc}
\hline & \multicolumn{2}{c}{$\begin{array}{c}\text { Preparation Time } \\
\text { (Minutes) }\end{array}$} & Regeneration (\%) & Transformants (\%) \\
\cline { 2 - 4 } Infection Methods $^{1}$ & Inoculation $^{2}$ & Co-cultivation ${ }^{3}$ & & \\
\hline SY(n=16) & 02 & 30 & 88.8 & 75 \\
FD(n=16) & 03 & 30 & 0 & 0 \\
NS(n-14*) & 03 & 100 & 33.3 \\
\hline
\end{tabular}

${ }^{\mathrm{T}} \mathrm{SY}$ - syringe method; FD - leaf disks method; NS - nodal segments method. ${ }^{2}$ Time required to establish the contact of the explants with the bacterium. ${ }^{3}$ Co-cultivation with the bacterium Agrobacterium tumefaciens. Wc - without co-cultivation. *Two events were lost.

Using the syringe and nodal segments methods, the greatest regeneration rates obtained were 88.8 and $100 \%$ respectively, while for the leaf disk method no plant regeneration was observed. In terms of transformation efficiency, $75 \%$ of the syringe explants were transformed with the exogenous gene contrasting with nodal segments that gave only $33.3 \%$ transformants. Our results regarding transformants percentages were higher when compared to data that has been reported for plant model systems. In general, the transformants percentages reported for A. thaliana were from 13.7 to $38.5 \%$ (Van der 
Graaff et al. 1996; De Buck et al. 2000). The percentages reported for N. tabacum were similar to A. thaliana, ranging from 38.5 to $50 \%$ (An et al. 1985; De Buck et al. 2000).

Although most of the plant transformation methods use leaf disks, the efficiency is not as high as we obtained using nodal segments, as can be observed in Ribeiro et al. (2010). The use of leaf disks in the process of infection and production of genetically transformed plants is very common, either through the inoculation methods in petri dish containing A. tumefaciens in suspension or in polypropylene tubes, with various immersion times.

In the syringe and nodal segments methods, A. tumefaciens solution was applied directly to meristematic tissue; this could explain the higher regeneration efficiency. Meristem tissue has high differentiation capacity and consequently allows for faster plant regeneration.

In our trials with the leaf disks method, morphogenesis was interrupted by the oxidation of leaf disks and therefore, no plant regeneration was achieved. These effects could be reduced by the application of phytoregulators such as BAP (6-benzylaminopurine) and 2,4-D (dichlorophenoxyacetic acid) to maximize regeneration responses.

The development of the explants differed among the methods, with results more quickly achieved by the syringe method. The implementation of the process was faster for the syringe method when compared to the nodal segments and leaf disks methods because it did not require time for inoculation of the bacterium and no co-cultivation of the explants with $A$. tumefaciens. The syringe method was also faster when compared to other reported methods that require from one hour (Mayo et al. 2006) to overnight growth (Horsch et al. 1985) for the co-cultivation period.

Various researchers have succeeded in the transformation of tobacco using transgenes from various species (Wan et al. 2009; Zhang et al. 2009). We achieved satisfactory results, i.e., increased transformant percentages in a reduced time, using a fast method to obtain genetically transformed plants.

\section{CONCLUSIONS}

The infection technique through syringe punctures in nodal segments of tobacco was the most efficient for the generation of genetically transformed plants in tobacco. The efficiency was significantly improved over that obtained with previously published procedures.

\section{ACKNOWLEDGMENTS}

The authors thank FAPESP (Foundation for Research Support of the State of São Paulo) (process number - 2014/24464-9) for the research grant awarded to the first author.

\section{REFERENCES}

An G, Watson BD, Stachel S, Gordon MP, Nester EW (1985). New cloning vehicles for transformation of higher plantas. EMBO J. 4:277-284.

Begcy K, Mariano ED, Gentile A, Lembke CG, Zingaretti SM, Souza GM, Menossi M (2012). A novel stress-induced sugarcane gene confers tolerance to drought, salt and oxidative stress in transgenic tobacco plants. PLoS ONE. 7(9), e44697. https://doi.org/10.1371/journal.pone.0044697. 
Bottino PJ, Raineri D, Nester EW, Gordon MP (1989). Agrobacterium-mediated DNA transfer. J. Tissue Cult. Methods 12:135-138.

Brasileiro ACM and Aragão FJL (2010). The Agrobacterium system: from the soil to the laboratory. In: In vitro culture of plants (ed. Cid, L.P.B.). Brasília: Embrapa Technological information, pp: 275-303.

De Buck S, De Wilde C, Van Montagu M, Depicke A (2000). T-DNA vector backbone sequences are frequently integrated into the genome of transgenic plants obtained by Agrobacterium-mediated transformation. Mol. Breed. 6:459-468. https://doi.org/10.1023/A:1026575524345.

Doyle JJ and Doyle JL (1987). A rapid DNA isolation procedure for small quantities of fresh leaf tissue. Phytochem. Bull. 19: 11-15.

Gelvin SB (2003). Agrobacterium-mediated plant transformation: the biology behind the "gene-jockeying" tool. Microbiol. Mol. Biol. Rev. 67(1):16-37. http://doi.org/10.1128/MMBR.67.1.16-37.2003.

Horsch RB, Fraley RT, Rogers SG, Sanders PR, Lloyd A, Hoffmann N (1984). Inheritance of functional foreign genes in plants. Science 223 (4635):496-498. http://doi.org/10.1126/science.223.4635.496.

Horsch RB, Fry JE, Hoffmann NL, Eichholtz D, Rogers SG, Fraley RT (1985). A simple and general method for transferring genes into plants. Science 227:1229-1231. http://doi.org/10.1126/science.227.4691.1229.

Kim SR, Lee J, Jun SH, Park S, Kang HG, Kwon S, An G (2003). Transgene structures in T-DNA-inserted rice plants. Plant. Mol. Biol. 52: 761-773. https://doi.org/10.1023/A:1025093101021.

Klee HJ, Horsch RB, Rogers SG (1987). Agrobacterium-mediated plant transformation and its further applications to plant biology. Ann. Rev. Plant Physiol. 38:467-486. https://doi.org/10.1146/annurev.pp.38.060187.002343.

Mayo KJ, Gonzales BJ, Mason HS (2006). Genetic transformation of tobacco NT1 cells with Agrobacterium tumefaciens. Nat. Protoc. 1: 1105-1111. http://doi.org/10.1038/nprot.2006.176.

Murashige T and Skoog F (1962). A revised medium for rapid growth and bioassays with tobacco tissue culture. Physiol. Plant. 15: 473-497. https://doi.org/10.1111/j.1399-3054.1962.tb08052.x.

Nester EW, Gordon MP, Amasino RM, Yanofsky MF (1984). Crown Gall: A molecular and physiological analysis. Ann. Rev. Plant Physiol. 35:387-413. https://doi.org/10.1146/annurev.pp.35.060184.002131.

Olhoft PM, Flagel LE, Somers DA (2004). T-DNA locus structure in a large population of soybean plants transformed using the Agrobacterium-mediated cotyledonary-node method. Plant Biotechnol. J. 2: 289-300. https://doi.org/10.1111/j.1467-7652.2004.00070.x.

Ribeiro JM, Bastos DC, Oliveira EAG, Souza JAM, Pinto MST, Hansen EET (2010). Transformation of tobacco plant (Nicotiana tabacum L.) with the recombinant hepatits B vírus genes 35SHBsAg and 35SHBsAg ER. Biotemas. 23: $1-11$.

Ribeiro-Neto LV, Oliveira AP, Lourenço MV, Bertoni BW, França SC, Rosa-Santos TM and Zingaretti SM (2015). Improving plant transformation using Agrobacterium tumefasciens. Genet. Mol. Res. 14: 66956698.https://doi.org/10.4238/2015.June.18.13.

Sallaud C, Meynard D, van Boxtel J, Gay C, Bès M, Brizard JP, Larmande P, Ortega D, Raynal M, Portefaix M, Ouwerkerk PB, Rueb S, Delseny M, Guiderdoni E (2003). Highly efficient production and characterization of TDNA plants for rice (Oryza sativa L.) functional genomics. Theor. Appl. Genet. 106: 1396-1408. https://doi.org/10.1007/s00122-002-1184-x.

Sambrook J and Russell DW (2001). Molecular cloning: a laboratory manual. 3rd ed. New York: Cold Spring Harbor Laboratory Press.

Sparkes IA, Runions J, Kearns A, Hawes C (2006).Rapid, transient expression of fluorescent fusion proteins in tobacco plants and generation of stably transformed plants. Nat. Protoc. 1: 2019-2025. https://doi.org/10.1038/nprot.2006.286.

Van der Graaff E, Den Dulk-Ras A, Hooykaas PJJ (1996). Deviating T-DNA transfer from Agrobacterium tumefaciens to plants. Plant Mol. Biol. 31:677-681.https://doi.org/10.1007/BF00042239.

Xiao B, Tan Y, Long N, Chen X, Tong Z, Dong Y, Li Y (2015). SNP-based genetic linkage map of tobacco (Nicotiana tabacum L.) using next-generation RAD sequencing. $J$ Biol Res-Thessaloniki 22:11. https://doi.org/10.1186/s40709-015-0034-3.

Wan X, Tan J, Lu S, Lin C, Hu Y, Guo Z (2009). Increased tolerance to oxidative stress in transgenic tobacco expressing a wheat oxalate oxidase gene via induction of antioxidant enzymes is mediated by $\mathrm{H}_{2} \mathrm{O}_{2}$. J. Plant Physiol. 136: 3044.https://doi.org/10.1111/j.1399-3054.2009.01210.x.

Wu H, Sparks C, Amoah B, Jones HD (2003). Factors influencing successful Agrobacterium-mediated genetic transformation of wheat. Plant Cell Rep. 21: 659-668. https://doi.org/10.1007/s00299-002-0564-7.

Wu H, Sparks CA, Jones HD (2006). Characterization of T-DNA loci and vector backbone sequences in transgenic wheat produced by Agrobacterium-mediated transformation. Mol. Breed. 18: 195-208. https://doi.org/10.1007/s11032-006-9027-0.

Zhang G, Chen M, Li L, Xu Z, Chen X, Guo J, Ma Y(2009). Overexpression of the soybean GmERF3 gene, an AP2/ERF type transcription factor for increased tolerances to salt, drought, and diseases in transgenic tobacco. J. Exp. Bot. 60: 3781-96.https://doi.org/10.1093/jxb/erp214. 